\title{
Learner Agency, Dispositionality and the New Zealand Curriculum Key Competencies.
}

New Zealand Journal of Teachers' Work, Volume 11, Issue 2, 175-186, 2014

Jennifer Charteris

University of New England

\begin{abstract}
As more than just knowledge and skills, The New Zealand Curriculum (Ministry of Education, 2007) key competencies encompass dispositions for lifelong learning (OECD, 2005). A range of studies associate learner agency within the dispositions that are embedded in these key competencies (Carr, 2004; Hipkins, 2010; Hipkins \& Boyd, 2011). Drawn from self-determination theory (OECD, 2009; Ryan \& Deci, 2000), the competencies are strongly anchored in an essentialist frame-work. Interpreted this way, competencies can be likened to a virtual backpack that students carry about and draw from at will. A discursively constituted view of identity would suggest that this is not the case. Employing Davies' (2010) conception of a subject-of-thought, where the subject is under erasure, the paper explores what agency as dispositionality can look like when it is performatively constituted in a competence-oriented curriculum (Ministry of Education, 2007). Rather being attributed static, essentialised identities, students are co-constituted in classroom discourses. The research has implications for how educators recognise moments when students agentically mobilise personal, social and discursive resources (Davies, 1990) in the classroom. This article presents an argument for a dynamic theory of agency that incorporates a rhizomatic view of learner participation and interrupts essentialist interpretations of dispositionality. It opens up possibilities for new conceptions of key competencies as performative discursive practices.
\end{abstract}

\section{INTRODUCTION}

A poststructural interpretation of the New Zealand Curriculum (NZC) key competencies enables us to look differently at how learners take up agentic subject positions within and across classroom discourses. Poststructuralism disrupts an essentialised conception of agency as a static and innate quality that students can possess and thus troubles conventional humanist interpretations of key competencies. This view of a humanist self corresponds with a neoliberal view that we are islands governed by self-interest and competitive drives. It is a meritocratic regime in that if we thrive or fail it is our fault and we are to blame. A humanist individualised view the subject underestimates the influence of discourse on human activity. Davies warns that "we are everywhere caught up in the molar, over-coded 'striations' of government, shaped as entrepreneurial subjects who will be productive in the service of capitalism" (Davies, 2009, p. 628). Although New Zealand's 
commitment to key competencies emerged from the economic rationalism of the Organization for Economic Co-operation and Development (OECD, 2005), they do not need to be enacted in essentialist ways in schools. The aim of this article is to explore a poststructural interpretation of learner agency as an embedded element in the NZC.

The notion of learner agency is deeply embedded in The NZC key competencies as "the capabilities that young people need for growing, working, and participating in their communities...The school curriculum should challenge students to use and develop the competencies across the range of learning areas and in increasingly complex and unfamiliar situations" (Ministry of Education, 2007, p. 38). Davies and Harré (1990) argue that individuals can exercise agency in relation to how they take up and act on classroom discourse practices. A poststructural paradigm "recognises both the constitutive force of discourse, and in particular of discursive practices and at the same time recognises that people are capable of exercising choice in relation to those practices" (Davies \& Harré, para, 8).

A humanist notion of self constructs an unproblematic conception of the learner where he/she is in control of his /her environment and is selfdetermining and self-regulating. Vassallo (2013), adopting a Freirean view, problematises this sovereign interpretation of self: "teaching students to regulate their learning can be tied to a curriculum of obedience, subordination, and oppression" (p. 563). A poststructural reading of the subject turns from an essentialising conception of the learner to embrace possibilities for a dynamic and emergent view of curricula. It suggests that learners can have ongoing opportunities to take up agentic subject positions in classroom discourses rather than being classified arbitrarily (e.g. by learning style).

The study comprises a discourse analysis of an episode in a year 9 science classroom in a regional high school in Aoteroa/ New Zealand. In the first part of the article I outline learner agency literature and suggest possibilities for a poststructural interpretation of the New Zealand key competencies. I then detail the methodological basis for the study and use a rhizomatic sample of classroom data to illuminate agency in action. The article concludes with a summary of the contribution this research can make to how teachers and academics may be able to conceptualise agency in the New Zealand curriculum.

\section{THE NEW ZEALAND CURRICULUM}

In the NZC document (Ministry of Education, 2007) key competencies are listed as: using language symbols and text; thinking; relating to others; participating and contributing and managing self. They provide a rationale for continuous improvement with a major focus on change, flexibility and education for the market. The competencies provide a vehicle for enacting the vision espoused in the New Zealand Curriculum (2007) for young people to be "confident, connected, actively involved, lifelong learners" (p. 8).

Online material published to supplement the NZC by the New Zealand Ministry of Education (2010) outlines that "key competencies are about developing the dispositions and sense of agency that not only empower the individual but help them better understand and negotiate the perspectives and values of others, contributing towards more productive and inclusive workplaces 
and societies" (paragraph, 3). Dispositionality, as an orientation to action, aligns with attributes that have been deemed important for lifelong learning (Carr, 2008). A range of studies highlight that agency is embedded in key competencies as dispositions (Carr, 2004; Hipkins, 2010; Hipkins \& Boyd, 2011). In this article, I explore how poststructural theory can help to subvert and reframe the notion of dispositionality as it is embedded in curricula discourses across the OECD, in particular The New Zealand curriculum.

\section{SUBJECTIVITITES}

Central to the argument that I advance is the conception that rather than fixed identities, subject positions (subjectivities) are an effect of discourse and therefore agency is discursively produced through positioning. Liberal humanist discourse prioritises individuality and constitutes teachers and students as unified subjects with inherent characteristics. Arguing against this position, Davies (2010) describes a 'subject-of-will' "as a rational responsible individual that we labour to bring into being as 'an idealised image of ourselves" (p. 55). Furthermore, Davies writes that according to a humanist individualistic perspective, identity is a means of gaining recognition, competing against others and being seen to have value that makes us both more vulnerable and less capable of agency. In contrast, Davies' (2010) 'subject-of-thought' (p. 54) is focused on the possibilities of what may emerge when learners are able to take positions where they can recognise what is assumed, what can be accomplished, and what can be imagined. The poststructuralist conception of the subject that Davies (2010) conceptualises as under erasure can act agentically through the way they take up, resist, ignore and even subvert discourses. I suggest that agency as a central element of the NZC key competencies is a dynamic phenomenon that is in constant motion.

\section{REFLEXIVE AGENCY AND RHIZOMES}

Rather that being something innate Barad (2007) argues that "agency is an enactment, not something that someone or something has" (p. 235). Agency has a social dimension in that it is relationally co-constituted through position calls (Drewery, 2005) where others expect a certain type of response. The complexities of subjectivation are elemental to the arguments put forth on agency in this article. Davies (2006), using Butler (1995), describes a radically conditioned agency. Here subjects reflexively and critically examine their conditions of possibility and in doing so they can both subvert and eclipse the powers that act on them.

[T]o claim that the subject is constituted is not to claim that it is determined; on the contrary, the constituted character of the subject is the very precondition of its agency. For what is it that enables a purposive and significant reconfiguration of cultural and political relations, if not a relation that can be turned against itself, reworked and resisted? (Butler, 1995, as cited in Davies, 2006, p. 426)

It follows that one's capacity for reflexive agency is mediated by the discourses available, how others position one socially as well as one's desire or wherewithall to take up identity affordances. Agency is therefore not 
deterministic in that one can take action through the use of discourse. This capacity to act upon discourses can be likened to rhizomatic activity. As Deleuze and Guattari (1987) observe, "a rhizome or multiplicity never allows itself to be overcoded, never has an available supplementary dimension over and above its number of lines" (p. 9). Davies (2006) uses rhizomatic imagery to conceptualise agency as lines of flight that "must escape the forces and codes that would oppose them" (Davies, 2009, p. 628). These rhizomatic movements mobilise potential lines of becoming otherwise (Wallin, 2010).

\section{THE STUDY}

The research was conducted in is a regional Aotearoa /New Zealand school where the teachers were engaging in 'Teaching as Inquiry' (Ministry of Education, 2007) to implement the NZC. To explore the discursive activity in the year nine classroom presented in this study, I videoed the classroom interactions, conducted observations and interviews with the students and teacher. Informed consent was gained from participants and pseudonyms are used. Discourse analysis as a methodological approach enabled me to examine how the learners were constituted in the classroom (Anderson, 2009). Gee (2011a) differentiates between macro and micro elements of discourse which he calls big ' $D$ ' and small ' $d$ ' discourses. Through mapping macro (big ' $D$ ') level classroom interactions, I was able construct classroom cartographies of the interplay between these discourses as a rhizo-textual analysis (Honan \& Sellers, 2006). Considering the classroom relationships as rhizomatic facilitated an examination of how the teacher and students are both constituted within the classroom discourses and, in turn, act upon them as they interact with their peers and teachers. I looked at the interplay of activity to chart the learners' and teacher's actions as subjects-of-thought (Davies, 2010). Honan and Sellers inform us that

...discourses operate within texts in a rhizomatic fashion, intersecting and separating, over and under lapping. A rhizo-textual analysis involves mapping these discursive lines, following pathways, identifying the intersections and connections, finding the moments where the assemblages of discourses merge to make plausible and reason(able) sense to the reader. $(2006$, p. 3 )

Alvermann (2000) who first developed the notion of rhizomatics as a methodological approach highlights how it can map various and often contradictory work, ideas and concepts. "Such 'disparate phenomena' can be drawn together to connect diverse fragments of data in ways that produced new linkages and revealed discontinuities" (Alvermann, 2000, p. 118). These discourses as 'disparate phenomena' can be seen in the episode of classroom activity below.

\section{The Classroom Episode}

The following is a transcript of the classroom talk that took place in the first 15 minutes of a science lesson in a regional New Zealand high school. PJ shares an image that he found in Google images of a shark behind some divers. It is similar to the image his teacher, Jan, showed the class the day before except the divers are different. PJ, through his investigation in his own 
time at home, discovers that his teacher's image is a hoax and he volunteers to share it with his peers. In this data we can see discourses signaled through the data as the teacher and students make shifts between them. PJ uses the computer and data projector to project the shark on the wall and Jan stands back inviting him to speak about the shark. Although Jan questions him before the class, inviting him to speak, he responds mostly to her and in a quiet voice. The students discuss the image excitedly. The italicized titles in the data sample comprise the macro discourses in play. Although there are multiple discourses circulating all the time in the classroom, critical thinking and teen peer discourse demonstrate learner agency as lines of flight. PJ, although quiet compared to others in the class, has a driving role in the activity in that he instigated the episode and manoeuvres Jan to ventriloquise for him.

\section{Critical Thinking}

Jan: So there it is there. Look what it says. It says 'a photo hoax.' Do you know what a hoax means?

Jan: (Jan waits a few seconds but no one responds.) If something is a hoax it's a fake. It's a trick.

Henare: Most probably a shark in a tank or something.

(The students comment among themselves.)

Jan: So PJ. (Jan raises her voice to speak over the students' voices.)

PJ how did you find that? How did you actually find that?

\section{Discourse Move to Teen Peer Discourse (Deterritorialization)}

Blake: Oh look! Go down! Go down! (Blake sees another shark image that catches his eye and asks PJ to scroll down further in Google images.) Look at that shark! (Blake interrupts Jan with his exclamation. The students all begin to talk. Jan holds up hand to signal to everyone to listen to her.)

Jan: How did you actually find that? (Jan turns to look at the whiteboard.)

Jan: Shhhhh! (PJ returns to the Google images search page and clicks on another shark picture.

Henare: (Henare describes this shark loudly over PJ.) It's not the fulla being munched. It's the shark going over the top of the fulla.

PJ: I went into images. (Almost inaudibly.)

(Thor, standing in the middle of the classroom, stops throwing darts to watch the screen. He walks to his seat, picks up an exercise book and sits down.)

Jan: So you went into images. Did you do that because you thought...?

Blake: Look at the shark behind that surfer! (Looking at Google images, Blake interrupts Jan and speaks loudly over the top of PJ.)

PJ: (PJ speaks inaudibly, distracted by Blake. The other students comment. PJ projects another shark that he finds in Google images on the screen. It takes everyone's attention.)

Jan: OK.

Jan: So PJ he looked at the photo a lot more critically. Didn't he?

(PJ looks at other images on the Google images page and find an image of a shark hanging upside down. He enlarges this shark. The 
students all lean forward to look closely. PJ bends over the small computer screen for a better look.)

Thor: Farrr! What is that? (Thor leans forward looking closely at the image $\mathrm{PJ}$ has projected onto the big screen.)

Jan: What is that? (Jan tilts her head to scrutinise the image.)

Henare: It's a shark caught in a net and it's hanging over like this. (Henare makes the shape with his hands. Jan goes over to look at the image from Henare's angle.)

Blake: Where's its mouth?

PJ: Down the bottom. (PJ enthusiastically points to the screen.)

\section{Discourse Move Critical Thinking (Reterritorialization)}

Jan: Oh Ok. (Sounding intrigued) Can you go back to the shark photo?

Blake: Oh most of its face is missing.

Jan (PJ brings up original hoax picture). OK. So when PJ looked at it yesterday he didn't say anything but obviously you looked at it a lot more critically that what I did - and what we did. And he thought that doesn't sound quite right having that big shark. How come it didn't chase the boy when he went back to the boat?

Blake: (Comments inaudibly)

Henare: The flash

Jan: Yeah somebody talked about the flash in the camera. (Students start talking.)

Jan: (Responding to someone inaudible) Yeah

Jan: So I think - Thank you PJ. Cos we now know. Maybe we need to be a little more critical of what we are looking at. Maybe we have to sort of think - 'Ahh! Now I am not necessarily going to believe everything that I see. I am not going to believe everything I get told.' (Jan moves to begin the next part of the lesson.)

\section{KEY COMPETENCIES, AGENCY AND DISPOSITIONALITY}

Rather than 'having' agency to transfer competencies from one situation to the next, competencies are produced and enacted as learners make moves across discourses. During the episode PJ as a subject-of-thought was constituted agentically when he made moves to initiate learning. He initially drew from critical thinking discourse to confront Jan with the news that the hoax was a fake. He also made a discourse move to take up teen peer discourse in order to be accepted in his peer group. It is likely that he spoke very quietly so as not to appear to his peers as the teacher's favourite or 'pet' and risk their disapproval.

PJ demonstrated key competencies (managing self, relating to others, thinking, participating and contributing, using language symbols and texts) to agentically initiate learning in the classroom. PJ enacted the thinking key competency as he searched for the shark image and found further evidence to confirm that the picture was a hoax. He prompted Jan to take up critical thinking discourse and, in turn, she constituted him as a 'critical thinker.' When I later interviewed Jan, she reported that $\mathrm{PJ}$ and his peers spoke about the need to be critical of Internet images in the days after the episode. PJ also pointed out in 
his interview that he caused others to think critically through sharing the hoax with them.

This research is timely in that, although agency is inherent as a dispositional attribute of the NZC competencies (Carr, 2004; 2008; Ministry of Education, 2010), there can be different interpretations of what agency is about. Hipkins $(2006$; 2012) observes that some schools can be reluctant to move beyond what they know and can do because they see competencies as straightforward and assume that they already address them. She cautions that this can lead to very superficial readings of the NZC. Classrooms awash with a rich and varied array of discourses and therefore learner agency cannot be reduced to something that is simply innate and possessed by the individual. For this reason it is important to resist reductive interpretations of agency as simply a student's orientation to learning.

A product of discourse, agency is co-implicated in social contexts as learners take up subject positions. Learners have the capacity to recognise their positioning and resist and subvert discourses, just as PJ took a line of flight to subvert critical thinking discourse to share further images of sharks with his peers. Through these opportunities for emergence (Somerville, 2007), identities can be made and remade. Competencies manifest when learners take up subject positions through discursive interactions.

The research aligns with the findings of Hamilton, Farruggia, Peterson and Carne's (2013) study into the NZC key competency implementation processes and strategies used by 5 economically diverse secondary schools. They identified that the schools that were more successful at integrating the KCs into their curriculum were characterised by a rethinking of pedagogy and teaching practice. Nevertheless, in the middle of busy classrooms it may be challenging for teachers to recognise how subtle shifts in discourse can relate to student learning. These learning opportunities or rhizomatic moments occur regularly in classrooms, however, as I have pointed out previously, students can enact competencies in unexpected and unsanctioned ways and students' disposition to risk-take and persist in a self-developed agenda can be overlooked by practitioners (Charteris, 2013). Carr, et al. (2008) point out that key competencies encompass inclinations and a sensitivity to opportunities to learn. Because of this 'fuzziness,' they suggest that there is a need for teachers to "notice and recognise differently" ( $p .83$ ) so that meanings can be negotiated and to co-constructed so they "will be able to navigate their way across boundaries of content and culture" (p. 83). The example demonstrates Jan's "different noticing and recognising"' in that she was able to take a line of flight to a different trajectory to the one that she had planned for the lesson that day. It aligns with Mayes and Groundwater-Smith's (2013) assertion that "in seeking to promote students' agency, practitioners must be receptive to the multiplicity of responses to the invitation to adopt alternation positions" (p. 11).

In her key competency 'thinkpiece' Glogowski (2013, p. 65) observes that the complexity of key competencies has given rise to the use of rubrics - a practice that risks "reducing the key competencies to a list of behaviours that can be ticked off or graded on a simple Likert scale and recorded on school reports." She argues that

[N]ot only does this risk 'surface level' interpretation of the key competencies but also brings into question how these various 
'indicators' of competence were arrived at; how do/do they take account of different individual and cultural traits and valued behaviours and attitudes? Do they take account of how consistently competence is demonstrated across a range of different learning areas and contexts, both culturally familiar and unfamiliar?

Rubrics, as Hipkins (2009) has pointed out, can fail to capture the richness and complexity of student learning. Therefore the practice of devising predetermined descriptors from which students can be 'rubricised' needs to be challenged. Hipkins writes "...rubrics...cannot take account of the situated, contextualised, participatory and emergent nature of the learning" (p. 15). She argues that "the relationships and connections that emerge and evolve over the course of the learning experience...could simply fade away unnoticed...[without] attention to context and action, instances when powerful new connections open up for individuals or groups" (p.15).

\section{CONCLUSION}

Considering the political climate in many schools where there can be pressure for teachers to achieve specific learning outcomes for (not necessarily with) students, divergent and emergent moments when students demonstrate agency by spontaneously and agentically initiating learning can be overlooked. As a small qualitative study, this research does not generalise, however it offers a heuristic to look at how we can think about dispositional learning differently, as discursively located and dynamic. It has implications for the ways in which key competencies can be interpreted and strengthened in classrooms. As the capabilities identified in the NZC, competencies are embedded across a range of discipline discourses. When students appropriate agentic learner subject positions, they use and strengthen key competencies. Classrooms that embody the spirit of the NZC with its corresponding emphasis on learner agency are places that potentially afford students opportunities to take up agentic positions in discourse. 


\section{REFERENCES}

Alvermann, D. (2000). Researching libraries, literacies and lives: A rhizoanalysis. In E. St. Pierre \& W. Pillow (Eds.), Working the ruins. Feminist poststructural theory and methods in education (pp.114-129). New York, NY: Routledge.

Anderson, K. (2009). Applying positioning theory to the analysis of classroom interactions: Mediating micro-identities, macro-kinds, and ideologies of knowing. Linguistics and Education, 20, 291-310. DOI: 10.1016/j.linged.2009.08.001

Barad, K. (2007). Meeting the universe halfway: Quantum physics and the entanglement of meaning. Durham, United Kingdom: Duke University Press.

Charteris, J. (2013). Learner agency: A dynamic element of the New Zealand key competencies. Teachers and Curriculum Journal, 13, 19-25. DOI: 10.15663/tandc.v13i0.7

Davies, B. (1990). Agency as a form of discursive practice: A classroom scene observed. British Journal of Sociology of Education, 11(3), 341-361.

Davies, B. (2006). Subjectification: The relevance of Butler's analysis for education. British Journal of Sociology of Education, 27(4), 425-438. http://www.jstor.org/stable/30036154

Davies, B. (2009). Deleuze and the arts of teaching and research. International Journal of Qualitative Studies in Education, 22(5), 625-630.

Davies, B. (2010). The implications for qualitative research methodology of the struggle between the individualised subject of phenomenology and the emergent multiplicities of the poststructuralist subject: the problem of agency. Reconceptualizing Educational Research Methodology, 1(1), 54$68 . \quad$ Retrieved from www.rerm.hio.no/index.php/rerm/article/download/10/8

Davies, B., \& Harré, R. (1990). Positioning: The discursive production of selves, Journal for the Theory of Social Behaviour, 20(1), 44-63. Retrieved from http://www.massey.ac.nz/ ALock/position/position.htm

Deleuze, G. \& Guattari, F. (1987). A thousand plateaus: Capitalism and schizophrenia. (B. Massumi, Trans.). Minneapolis, MN: University of Minnesota Press.

Drewery, W. (2005). Why we should watch what we say: Position calls, everyday speech and the production of relational subjectivity. Theory \& Psychology, 15(3), 305-324. doi: 10.1177/0959354305053217

Glogowski, S. (2013). Thinkpiece: The key competencies: Do we value the same outcomes and how would we know? Teachers and Curriculum, 13, 64- 65.

Hamilton, R., Farruggia, S., Peterson, E., \& Carne, S. (2013). Key competencies in secondary schools: An examination of the factors 
associated with successful implementation. Teachers and Curriculum, 13, 17- 55.

Hipkins, R. (2006). The nature of key competencies. A background paper. Wellington: New Zealand Council for Educational Research.

Hipkins, R. (2009). Determining meaning for key competencies via assessment practices. Assessment Matters, 1, 4-19.

Hipkins, R. (2010, October). More complex than skills: Rethinking the relationship between key competencies and curriculum content. Paper presented at the International Conference on Education and Development of Civic Competencies, Seoul. Retrieved from http://www.nzcer.org.nz/system/files/more-complex-than-skills_0.pdf

Hipkins, R., \& Boyd, S. (2011). The recursive elaboration of key competencies as agents of curriculum change. Curriculum Matters, 7, 70-86.

Honan, E., \& Sellers, M. (2006, November). So how does it work? - Rhizomatic methodologies. Paper presented at the Australian Association for Research in Education Conference. Retrieved from http://www.aare.edu.au/06pap/hon06003.pdf.

Mayes, E., \& Groundwater-Smith, S. (2013). Ricoprire posizioni alternative: Student voice, riflessione e riforma [Performing alternative positions: Student voice, reflection and reform]. In V. Grion and A. Cook-Sather (Eds.), Student Voice. Prospettive Internazionale e Pratiche Emergenti in Italia [IStudent Voice. International Perspectives and Emergent Practices in Italy]. (pp. 193-211), Milan, Italy: Guerini.

Ministry of Education. (2007). The New Zealand Curriculum. Wellington, NZ: Government Printer.

Organisation for Economic Cooperation and Development (OECD). (2005). The definition and selection of Key Competencies: Executive summary. Paris. Retrieved from www.pisa.oecd.org/dataoecd/47/61/35070367.pdf

Organisation for Economic Cooperation and Development (OECD). (2009). PISA 2009. Assessment framework key competencies in reading, mathematics and science. Retreived from www.oecd.org/pisa/pisaproducts/44455820.pdf

Ryan, R., \& Deci, E. (2000). Self-determination theory and the facilitation of intrinsic motivation, social development, and well-being. American Psychologist, 55, 68-78.

Ministry of Education. (2007). The New Zealand Curriculum. Wellington, NZ: Government Printer.

Ministry of Education. (2010). National Standards and key competencies. Retrieved from http://keycompetencies.tki.org.nz/National-Standardsand-KCs

Somerville, M. (2007). Postmodern emergence. International Journal of Qualitative Studies in Education, 20(2), 225-243. 
Vassallo, S. (2013). Critical pedagogy and neoliberalism: Concerns with teaching self-regulated learning. Studies in Philosophy and Education, 32(6), 563-580.

Wallin, J. (2010). A Deleuzian Approach to Curriculum. Essays on a Pedagogical Life. Basingstoke, United Kingdom: Palgrave MacMillan

Manuscript Submitted: June 17, 2014

Manuscript Accepted: March 12, 2015 


\section{ABOUT THE AUTHOR}

JENNIFER CHARTERIS

University of New England

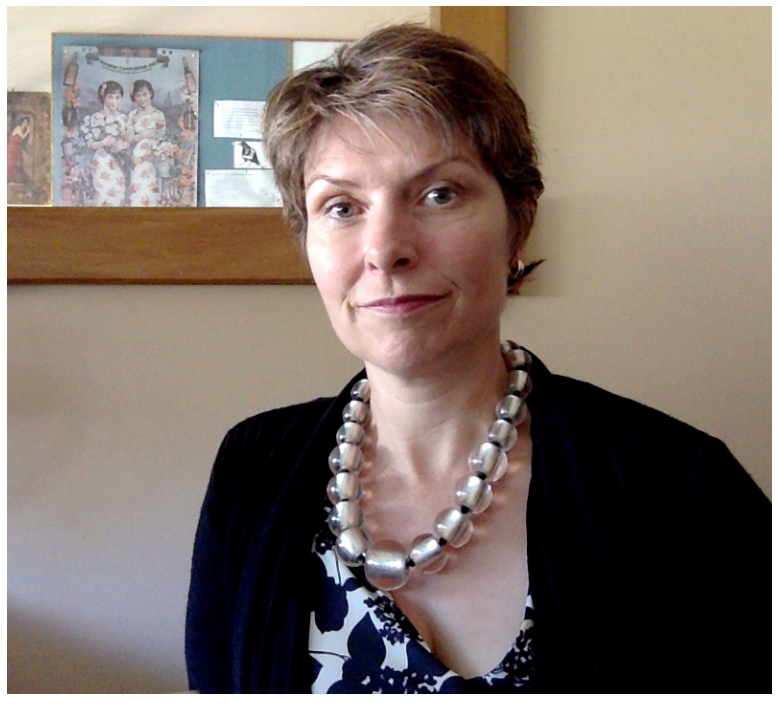

Jennifer is a Lecturer in the University of New England School of Education. With over 20 years teaching experience in the primary and secondary sectors, she has worked in both pre-service and inservice teacher education in New Zealand and Australia. Her research interests are in the area of assessment for learning, learner agency and teacher and student learning. She has published internationally in the area of teacher professional learning and learner agency. Jennifer currently teaches pre-service education courses that draw from educational psychology, assessment for learning and evidence-based practices in education.

Contact: jcharte5@une.edu.au 